\title{
System Analysis of Region Environmental Dimension
}

\author{
Gotfrids Noviks \\ Rezekne Academy of Technologies
}

\begin{abstract}
Areas of social systems - regions and their development is the key for national development, main vector of prosperity growth. There can be no prosperity without a strong and developed the country's regions. 0

The article dealt with regionics- science that subject of studies are relatively small regions at NUTS-3 level with its historically established determinate territory, the cultural and ethnic identity, their development problems in the environmental dimension aspect. There is analyzed one of the most identical Latvian region - Latgale.
\end{abstract}

Keywords: Regional studies, tangible and intangible resources, ecosystem services, Latgale region.

\section{INTRODUCTION}

Starting from the eighties of the 20th century industrialization, technical and scientific progress, the extension of international economic and market links, international cooperation, flow of information, knowledge, technology and innovation as well as movement of products, services and population and the interaction between the countries has led to a sharp increase in the processes of globalisation. But globalization trends are not clearly positive.

Mike Collins [1] analysing this process, lists 16 positive and 13 negative factors, which influence the people and national economic and social situation in relation to the consequences of globalisation. But there are additional negative moments associated with human historical existence territory identity, which greatly affects people's mental state and thus the performance incentives.

However, it can be argued that globalization is a total human development vector and, therefore, this process is inevitable. But at the same time actually exist and always will exist territorial social systems regions as global complex system building block.

Generalized region can be defined as the territory in which a set of specific characteristics is different from other areas, and which has the unity, the interconnection and interaction between inner elements and commonality, which is objective and logical result of the territorial development.

So, the region is a territorial system. The region has all the characteristics of complex systems, including space and time dimensions [2] structural elements and their mutual links, diversity, stability, resistance and self-learning, proper hierarchy [3].

The boundaries of the region are determined by the adopted parameters and criterions.
The homogeneity of the region is determined on the basis of the indicators that describe the nature of this area.

In the first stage of regional studies dominated economic organization and productive forces deployment aspects of territories. One of the first researchers in the science of regions can be considered German economist Johann Heinrich von Thünen, who in 1826 published his economic object placement concentric rings theory. Continuing this work the German scientist Carl Wilhelm Friedrich Launhardt in 1882.g. developed theory of industrial location and weight triangle method, which was based on transport costs (theory of the trace). Alfred Weber in 1929 formulated a least cost theory of industrial location, which is based on the total production and transportation costs minimization principle in the factory territorial deployment point selection.

Locating method continues to develop in the modern economic geography and regional economy. For example, this theory used in European Union's economic situation analysis [4].

German geographer W.Christaller in 1933 g. developed the central place theory - the geographical theory about optimal number of people in the urban environment, size, shape and mutual placement of the towns. German economist August Losch in 1939 developed the spatial concept of the economy, which is based on maximizing consumer prosperous space, but income is kept at an optimal level - with no aim to maximize.

At the same time developed other direction of regional studies, which was mainly based on the physical geographic characteristics of territory (geographer W.L.G.Joerg, geologist and geographer N.M.Fenneman, sociologist T.J.Woofter). P.V. de la Blach (1910) in his works described the social, 
political, geological, transport and historical aspects of regions as united complex.

American economist Walter Isard in the 50-ies of the 20th century brought together regional economic, geographical, ecological planning aspects as a whole thus creating a modern regional science methodology.

Regional science - interdisciplinary science that object of studies is a region - united by a whole complex of natural and human communities typical indicators spatially and historically determined territory.

Continuous economic development, despite its dynamism and expansion of global economic transformation, did not reduce the gap between individual regions characteristics.

Diversity of sub-national formations -regions is not only leveled - even sometimes it is intensified and deepened due to the fact that industrialization and its expression is highly dependent on the regional cultural and social diversity of structures (Trompenaars' and Hampden-Turner's cultural factors) [5].

Regions remains as the base unit of the world's territorial economic mosaic. M.Porter [6] found that the economic development level analysis should be changed from now existing dominant national to regional, due to the indisputable economic average development in the country overall non-compliance with the development of certain regions.

Exactly the regions are most closely related to ecology, environmental factors and resources of territory.

It is necessary to analyze the national development results, prospects and planning programs taking into account as a criterion not only all the national gross domestic product (GDP), but also the regional Gross Domestic Product (GDPR). This approach is currently used in the EU to analyze the relevant territory for the development of statistical data. According to the Council Regulation Nr.1059 / 2003, the EU has established territorial units in a hierarchical three-level classification for unified European statistical purposes (Nomenclature of Territorial Units for Statistics-NUTS) [7].

Regional science according to relatively small territories-at NUTS-3 level or less, identified as historically developed ethnic, cultural unit we advice to name as regionics.

Research areas of regionics are the regions' natural, tangible and intangible resources, ecological, historical, demographic, ethnic, religious peculiarities in their total interaction, their relationships qualitative and quantitative evaluation, the development process analysis and forecast.

Latgale region in Latvia correctly fit to this definition.

\section{MATERIALS AND METHODS}

Our research object - region, its nature and its development determinants in the context of the environmental dimension focusing attention on tangible and intangible natural resources.

The region as a complex system includes the structural elements of the following:

1. Environmental dimension functional blocks subsystems: ecology, natural resources, recreational resources

2. Socio-economic dimension functional blocks: population, economics, production and social infrastructure, market infrastructure.

3. Humanitarian dimension functional blocks: ethnic, national criteria of national identity, cultural and spiritual, religious characteristics, historical factors.

4. Administrative and political dimension functional blocks: an institutional infrastructure, administrative factors, the political structure.

One of the main factors, which determine development of the region is natural resources. Environment and natural resources from time immemorial have been the main drivers of regional development, and now they are playing one of the main roles, less as it was in previous times in region's economy (thanks to a wide inter-regional and international co-operation), but very high in human living structural and substantive unique characteristics.

Until the end of the 20th century regional economic development study models the environment - ecological component did not take into account.

Millennium Ecosystem Assessment (MA) expanded concept of ecosystem services.

Ecosystem services plays serious, and in some sectors determinant (eg., tourism, agriculture, forestry, etc.) role of regional socio-economic development.

The paper describes the types of regions according to their influencing factors, analysis ecosystem services and natural resources, and their role of regional development on the case of Latvian region Latgale.

\section{RESULTS AND DISCUSSION}

The analysis shows that all regions can be divided into two groups according to their genesis: the regions, which are based on natural, independent of human criteria and parameters (natural-physicalgeographic) and regions which developed by human activity - direct or indirect, targeted or unorganized.

The first group of regions are related to the natural processes in the environment, they are primary, that territory as the objective reality of the existence of determining factors. 
The second group of regions has two types ethnic- cultural regions developed historically during long period of time gradually (endogenous) and administrative, political (exogenous), created by the people, adopted the different levels of national or international laws, treaties, pacts and other legal instruments (table 1).

Accordingly, these regions influencing factors time, space, climatic and other role in regional development dynamic are very different.

Table 1

Regions characterized according to those influencing factors

\begin{tabular}{|c|c|c|c|}
\hline Dimension & Environment & Ethnic & Legal \\
\hline Regions & $\begin{array}{l}\text { Physical and geological, } \\
\text { geographical, nature }\end{array}$ & Cultural-ethnic, historical & Administrative and political \\
\hline Space factor & $\begin{array}{l}\text { Deterministic diffusion } \\
\text { boundaries through natural } \\
\text { processes }\end{array}$ & $\begin{array}{l}\text { Fugitive boundaries as a } \\
\text { result of historical people's } \\
\text { migration }\end{array}$ & $\begin{array}{l}\text { Strictly determinate limits laid down } \\
\text { in the decision of people }\end{array}$ \\
\hline Time factor & $\begin{array}{l}\text { Stable according to } \\
\text { geological time scale }\end{array}$ & $\begin{array}{l}\text { Stable according to long- } \\
\text { standing historical time scale }\end{array}$ & $\begin{array}{l}\text { Unstable, changing in a relatively } \\
\text { short time scale }\end{array}$ \\
\hline Other influencing factors & $\begin{array}{l}\text { Geological and global } \\
\text { climatic processes }\end{array}$ & $\begin{array}{l}\text { Human populations } \\
\text { migration and } \\
\text { accommodation processes }\end{array}$ & $\begin{array}{l}\text { Political, administrative, authoritarian } \\
\text { decisions }\end{array}$ \\
\hline
\end{tabular}

Natural regions are the most conservative, unchangeable, long-term, stable at least for many human generations - for the most part, many hundreds and thousands of years - the geological time scale intervals.

Historical endogenous regions are much more susceptible to changes in time - humanity's historical timeline intervals.

Administrative - political exogenous regions are most prone to perturbations during - human generation timeline. They are strongly influenced by various human activities factors - political, economic, administrative, including subjective, ambitious, violent, and so on.

At the same time, since these regions and their boundaries are legally defined and human activities are adequately regulated and regulated exactly within this range, they become determinants of life progress and development processes in these areas.

Also the boundaries of the political administrative regions are strictly determined.

Less accurate with quite a wide range of interactions (mixed) zone are historical (ethnic) regions.

Physical and geological natural regions can be sharply separated from each other by natural boundaries, but can also be a transient phase in each other - diffuse area.

Since all of these regional boundaries do not match (fig.1), but the most powerful effects on human and social activities gives the administrative regions and national boundaries, forms disagreements, conflict situations in humanitarian, socio-political, economic sphere, non-compliance in production and consumption of the resources, non-optimized production and operating conditions, unfavorable socio-economic environment, stress, tension between population groups.

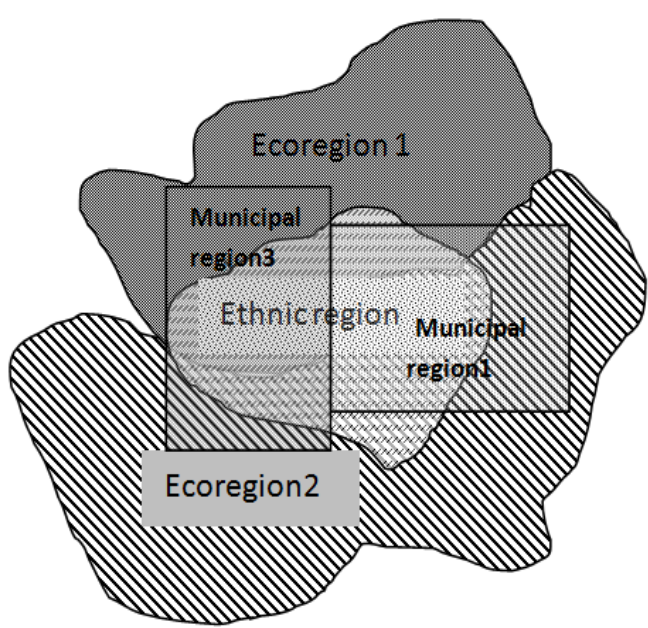

Fig.1. Inadequacy of the bounderies of different regions.

So, there is a discrepancy between social and geospatial region components mainly that each of them is developing at its own different laws and times.

Social components are developing and changing fast, geologically geographical - slow or for long time does not change at all and the in the most cases a man do not have any influence on these changes limited with modern scientific and technological development level.

Optimum conditions, which can develop in the region, are the ones where the administrative borders of the region coincides with the cultural-historical and physical-geographic.

This disagreement stimulated natural regions (bioregions) concept formation, which offers establish administrative regions borders based on ecological criteria and environmental conditions of territory. On that basis have been set up virtual countries directly in the boundaries of bioregion, such as Cascadia bioregion (includes two countries - US and Canadian sites) [9], bioregion Ozark plateau (within the US, but includes a territory of different states [10]. 
At the moment, as it was already mentioned, is becoming a popular concept of ecosystem services [11].

Under this concept understands all the benefits that a person can get directly from ecosystems relatively with no effort on his part - the product developed as a result of natural ecosystems existence.

European Environment Agency developed a common international classification of ecosystem services (CICE) [12] where services of nature are grouped into three sections:

- provisioning (nutrients, materials and energy, which ecosystems offers for human directly).

- regulation and maintenance (ecosystem functions which provide other ecosystem services).

- cultural (intangible benefits which can offer the ecosystems - physico and intellectual, mental and symbolic interactions with biota, ecosystems).

Ecosystem service concept focuses on goods which are produced by ecosystem, and thy are primarily related to the ecosystem biota.

However, they are only at the lowest level. In principle, any benefit obtained from the nature is not toll-free. Its withdrawal requires functioning of the human hand (even picking mushrooms). In addition, the quality of the benefit may be much higher if one carries additional forces for the collection and further processing.

Ecosystem service terminal value EV depends on the primary value of service $E_{0}$, as well as of service transformation coefficient of the $\mathrm{k}_{\mathrm{tr}}$, (which is usually more than one, but sometimes can also be negative) and benefit demand index $\alpha$, which characterizes the human desire to get this service.

$$
\mathrm{EV}=\left(\mathrm{E}_{0} * \mathrm{k}_{\mathrm{tr}}\right)^{\alpha}
$$

Ecosystem services need to be seen as the resource potential of the respective region, as well as the possible consequences of its use intensity (present or designed) - the ecosystem's ability to maintain their service functions further.

Index of load on the ecosystem $\mathrm{L}$ is calculated by formula

$$
\mathrm{L}=\mathrm{C} \delta / \mathrm{t} \beta \mathrm{g} \gamma,
$$

where $\mathrm{C}$ - environmental carrying capacity,

$\rho$ - environmental resistance to external effects parameter,

t- time of impact on the ecosystem

g- impact intensity,

$\beta, \gamma$-coefficients $(\beta=2-2.5, \gamma=2.5-4)$.

Optimally this parameter L must be more than 1 . In principle, all ecosystem's biotic and abiotic components can be used in human well-being.

So, the ecosystem service concept is actually just the common concept of "natural resources" conditionally separated part. Therefore, in our view, more appropriate is to operate with the concept of natural resources and to analyze their possibilities to use them, their prospects, accessibility and value.

Resources can be defined as any kind of tangible and intangible values and the sources from which one can obtain the relevant benefits according to the diverse human claims.

Type of the resource depends on the target to achieve which it can be used.

Is the goal - according to this are searched resources, which are necessary to achieve that objective. The objectives are manifold, in addition they changes and broaden in time, their nature is changing.

Human existence as an individual objective is different from the social group, community, national or global human development goals. These differences also change with time - in certain periods can be reduced, in other to grow and can sometimes move to the confrontation stage. Accordingly the range of resources changes, as well as attitudes towards them, their value, demand and availability. With equipment and technology development, human interest and demand changes and some types of resources loses its meaning, others become decisive.

So - the resource is variable during the time and dynamic concept.

Analyzing the resources of the region's environmental dimension point of view it is necessary to classify them differently.

At first, the resources can be primary and underlying or derived - developed after the transformation - a new type of secondary sources, of which it is possible to create the next generation of resources.

Second - different types of resources are not isolated from each other - they are linked to each other - they are a single complex system with interaction of elements and emergency processes between them.

Primary resources are natural resources which in turn can be divided by secondary criteria as biotic and abiotic, renewable and non-renewable, widely available and localized, used and potential. The listed resources provide human material welfare.

However, people's spiritual, aesthetic, psychological, internal comfort, curiosity desires provision are not directly related to the material values of resources. The ability of natural objects to meet people's spiritual requirements are intangible natural resources.

Their profit for man is derived by emotional, spiritual path based on a specific vision and environmental assessment of a given cultural symbolic experience within. [13,14,15]. Analyzing the resources from this point of view it can be concluded that:

1. Any natural object may become as a resource in the certain circumstances. 
2. Also, any waste formed by human activity, is actually a secondary technogenic resource.

3. All resources are virtually multipurpose.

4. For all resources, in addition to use of the material have to a greater or lesser extent intangible function- ability to directly interact through the sense organs of the human body and consciousness and thus influence the spiritual life and change the state of health.
So for analysis of regional environmental dimension we offer classification of natural resources, which includes 4 main groups of resources (table 2) substance resources: biotic and abiotic; resources of physical fields; complex agro-physical resources.

Each of these resources can be characterized by their role, which it executes or potentially is able to meet human residency of providing material, energy or non-material needs and desires.

Table 2

Classification of natural resources by the types and components (components: M-material, E-energy, N-intangible)

\begin{tabular}{|c|c|c|c|c|c|c|c|}
\hline \multirow[t]{2}{*}{ Nature resources } & \multirow[t]{2}{*}{ Groups } & \multicolumn{3}{|c|}{ Components } & \multirow[t]{2}{*}{ Available } & \multirow{2}{*}{$\begin{array}{l}\text { Prosp } \\
\text { ective }\end{array}$} & \multirow[t]{2}{*}{ Renewable. } \\
\hline & & $\mathrm{M}$ & $\mathrm{E}$ & $\mathrm{N}$ & & & \\
\hline \multirow[t]{2}{*}{ Biotic } & Flora & * & $*$ & $*$ & $*$ & & $*$ \\
\hline & Fauna & $*$ & & $*$ & $*$ & & $*$ \\
\hline \multirow[t]{3}{*}{ Abiotic } & Minerals & $*$ & $*$ & & $*$ & & \\
\hline & Water & $*$ & $*$ & $*$ & $*$ & & $*$ \\
\hline & Atmosphere & & $*$ & $*$ & $*$ & & $*$ \\
\hline \multirow[t]{7}{*}{ Physical fields } & Gravitation & & & $*$ & & $*$ & $*$ \\
\hline & Magnetic & & & $*$ & & $*$ & $*$ \\
\hline & Radiation & & & $*$ & & $*$ & $*$ \\
\hline & Seismic & & & $*$ & & $*$ & $*$ \\
\hline & Geothermal & & $*$ & & $*$ & & $*$ \\
\hline & $\begin{array}{l}\text { Electro } \\
\text { magnetic }\end{array}$ & & $*$ & $*$ & $*$ & & $*$ \\
\hline & Cosmic rays & & & $*$ & & $*$ & $*$ \\
\hline \multirow{5}{*}{$\begin{array}{l}\text { Agro-physical, } \\
\text { climatic, physio- } \\
\text { geographic }\end{array}$} & Soil & & & $*$ & $*$ & & $*$ \\
\hline & Climatic complex & & & $*$ & $*$ & & $*$ \\
\hline & Relief, topographic & & & $*$ & $*$ & & \\
\hline & Water-earth rate & & & $*$ & * & & \\
\hline & Protected natural areas & & & $*$ & $*$ & & \\
\hline
\end{tabular}

Physical fields and their complexes (agro-physical, climatic geographical) form natural conditions of a given region. They also have an intangible resource it is human existence environment from which he obtains daily life energy and the ability to live, to act. In contrast to the classic definition of resources this resource functions can be not only beneficial, but also the evil. It should be understood only that the concept of "evil" is just as subjective as "good". In nature there is no such category. Therefore, assessing the ecosystem or environmental services it is need to adopt a point of reference notional zero line, which is understood as a person's standard of living and welfare conditions. All factors which lowers these conditions can be expressed by a number with negative sign - and vice versa. Environmental conditions often can affect a person's life negatively - that is, they become negative natural resources. Their role in research on resources and their impact on regional development is analyzed quite rare. First, there are climatic factors, secondly, geophysical fields and cosmic radiation. Undoubtedly, any physical phenomena and physical fields influence on people can be the negative or positive, depending on the field intensity, changes in space and time and other parameters

Also the ecosystems not gives only a positive results on human existence. For example, about $90 \%$ of $\mathrm{NO}_{2}, 23-30 \%$ of $\mathrm{CH}_{4}$ emissions in the atmosphere, $25 \%$ of infectious diseases are linked to ecosystems. It means, that there are strong necessity for study the effects of field interacts with the human conditions of existence and elimination the negative consequences or modification them for benefits.

Let us analyze the most identically pronounced Latvian region Latgale. Latgale is a cultural and ethnic region in the Latvian eastern part. Evaluating the Latgale region it can be determined that the region is different from the other Latvian regions not only in it's own ethnic identity, but also from the point of view of the environmental dimension. Our research showed that there is a difference in the region's geological structure, geophysical field intensity, in the tangible and intangible resources.

Latgale region cultural and historical boundaries do not coincide with the set up NUTS-3 level Latgale planning region [fig.2] according to the European Council Regulation Nr.1059 / 2003, but it is pretty close. Therefore, the planning region statistical data is conditionally applicable for analyse this historical region.

Latgale Planning Region covers an area of 14550 $\mathrm{km}^{2}-22.5 \%$ of Latvia territory(fig1), while the number of inhabitants per 2016 year was 286,238, what means $14.4 \%$ of the Latvian population. 


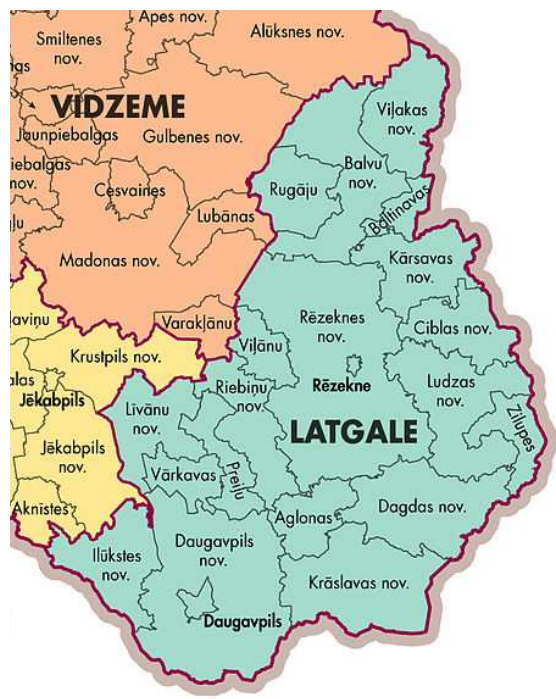

Fig. 2. Latgale planning region
The level of ecosystem service to this moment has not been evaluated in Latgale region as well as in the Latvia due to lack of more or less accurate statistical data. In Latvia there are only some local researches in this field [16] based on the experts' assessment methodology. But available data about Latgale generally show that the ecosystem services offered there are large and varied, but the scope of the use is incomplete. It is one of the factors which resulted in the Latgale region seriously lagging behind in their economic development from other Latvian regions.

According to the developed resource classification were assessed Latgale region's resources, including ecosystem services utilization rate for this moment.

The following table (table 3 ) shows the main types of Latgale region resources as the percentage of the optimal distribution of its components (the upper number) and its current utilization rate (lower number).

Table 3

Latgale region's resources, ecosystem services and the level of potential use

\begin{tabular}{|c|c|c|c|c|c|c|}
\hline \multirow{2}{*}{ Resource } & \multicolumn{2}{|c|}{ Material } & \multicolumn{2}{|c|}{ Energy } & \multicolumn{2}{|c|}{ Intangible } \\
\hline & $\%$ & character & $\%$ & character & $\%$ & character \\
\hline Forest & $40 / 50$ & $\begin{array}{l}\text { Wood as a } \\
\text { material, hunted } \\
\text { animals, berries, } \\
\text { mushrooms, } \\
\text { pharmaceutical } \\
\text { plants }\end{array}$ & $40 / 30$ & Wood as fuel & $20 / 10$ & $\begin{array}{l}\text { Rehabilitation, recreation, } \\
\text { tourism }\end{array}$ \\
\hline Surface water & $20 / 10$ & $\begin{array}{l}\text { Fish, aquatic } \\
\text { plants, water for } \\
\text { household }\end{array}$ & $10 / 10$ & $\begin{array}{l}\text { Hydropower } \\
\text { plants }\end{array}$ & $70 / 30$ & $\begin{array}{l}\text { Rehabilitation, recreation, } \\
\text { tourism }\end{array}$ \\
\hline Minerals & $90 / 30$ & All Minerals & $8 / 4$ & Peat & $2 / 0,5$ & Sapropel, therapeutic sludge \\
\hline $\begin{array}{l}\text { Geophysical and } \\
\text { cosmic fields }\end{array}$ & 0 & & $5 / 2$ & $\begin{array}{l}\text { Solar, wind, } \\
\text { geothermal energy }\end{array}$ & $95 / 0$ & $\begin{array}{l}\text { Vitagenic and pathogenic } \\
\text { effects on the body }\end{array}$ \\
\hline $\begin{array}{l}\text { Agro-physical and } \\
\text { climatic }\end{array}$ & 0 & & 0 & & $100 / 60$ & $\begin{array}{l}\text { Agriculture, livestock } \\
\text { farming, recreation, tourism }\end{array}$ \\
\hline $\begin{array}{l}\text { Protected natural } \\
\text { areas }\end{array}$ & 0 & & & & $100 / 40$ & $\begin{array}{l}\text { Cultural development, } \\
\text { environmental education, } \\
\text { intellectual interaction, } \\
\text { science, holistic approach }\end{array}$ \\
\hline
\end{tabular}

Latgale forests occupy $39 \%$ of Latgale territory and this is $78 \%$ of the average Latvian forest cover percentage. Latgale wood stocks representing $17 \%$ of total Latvian. Forest supply services is higher than the optimal due to too intensive deforestration for obtaining wood. However, incomplete are used forest other resources -intangible as well as tangible.

After the site area, which occupies a surface water, Latgale almost twice the average Latvian indicators, but their use efficient is quite low, with the exception of small hydro power plants. This position has exhausted its potential and further expansion of hydroelectric power threaten ecosystems existence.

In the field of mineral resources Latgale can be valued quite low compared to the total Latvian scene (fig.3) except clay resources. But all those also at this level is not currently being fully exploited.

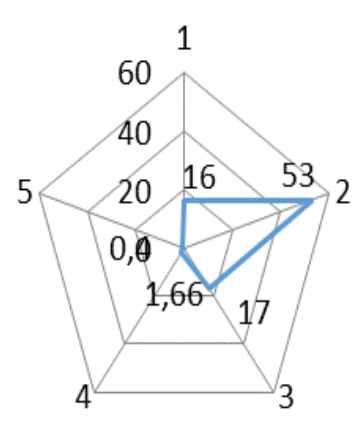

Fig.3 Latgale mineral and timber resources (\% of total Latvian resources) 1-dolomite, clay-2, 3-wood, sand-gravel 4-, 5-sapropel.

Exploiting of geophysical fields in Latgale currently is associated in a small quantity with wind and solar energy, but this energy potential is low also. 
Geophysical and cosmic fields significance in the region is mainly related to their observance in region territory economic planning.
In Latgale exists gravitational field anomalies, which have a positive impact on human health. The optimum gravity field anomaly range is between 20 to $45 \mathrm{mGal}$ (fig 4a).
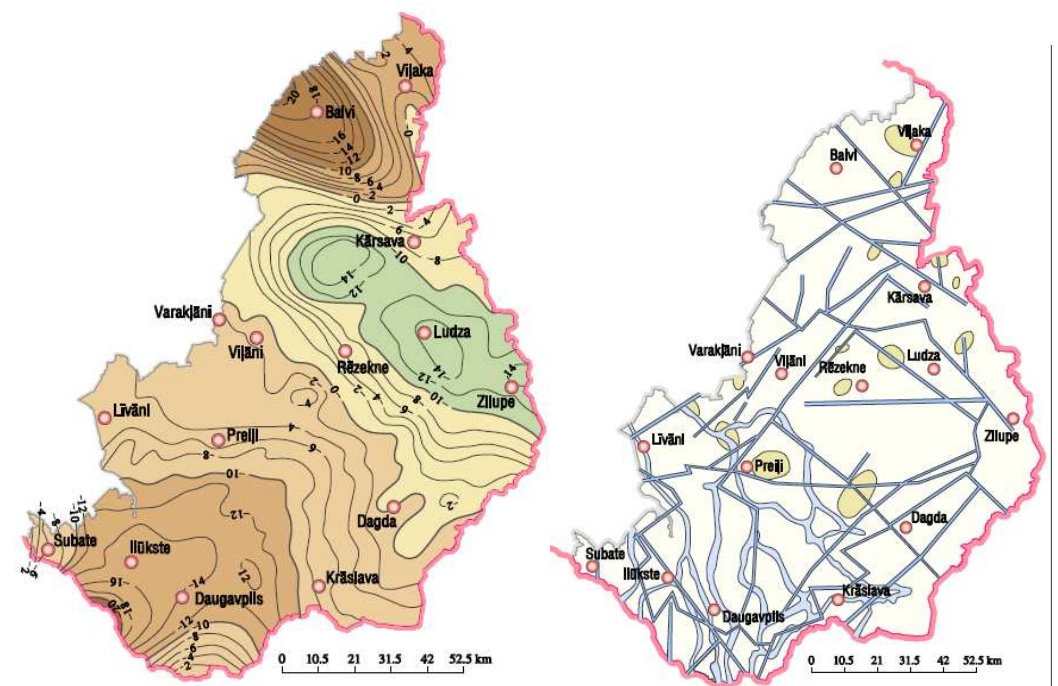

Fig.4 Latgale gravitational field anomalies (a) and tectonic fracture zones (b)

Latgale average magnetic field anomaly is + $44 \mathrm{nT}$. That fits in the interval optimal for human health in the range of -300 to $+300 \mathrm{nT}$ and is much lower than the average Latvian magnetic field anomaly (+ 261nT).

But in Latgale there are also geopathogenic areas where geophysical field becomes unfavorable to human life.

As Latgale rocks' crystalline basement is closer to the Earth's surface and has quite large quantity of fractures (see fig .4 b), there are areas with elevated radon release from the ground. Depending on the created by radon radiation level along with other fields can be given the positive - vitagenic, as well as negative - pathogenic effects on human. All of these factors is no met in territorial planning at Latgale and in Latvia currently.

Agrophysical and climatic fields in Latgale region is also different from other regions. Precipitation is lower than other regions -550-650 $\mathrm{mm}$ per year, temperature fluctuation range is wider, more continental climate, sum of active temperatures (ATS) is higher (1900 to 2100) as well as greater hydrothermic coefficient (1.8 to 1.9). (fig.5).

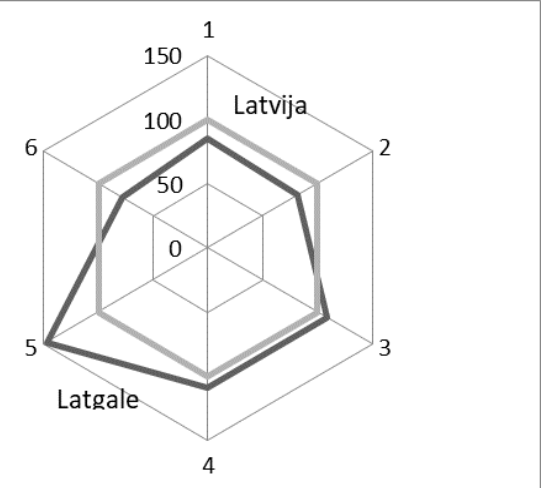

Fig.5.Latgales agro-climatic resources (\% of the average in Latvia) 1-precipitation, 2-mean temperature 3- sum of active temperatures, 4-hydrothermic coefficient 5- agricultural land (\% ratio), 6woodland (\% ratio).

Land used for agriculture is $44 \%$ from total territory of region which is more than the average over Latvia

Given the fact that the composition of soil in Latgale differs little from that in other regions can be assumed that in Latgale are high potential for agricultural development.

But the actual figures show that after production region seriously lags behind other regions level (fig.6). 


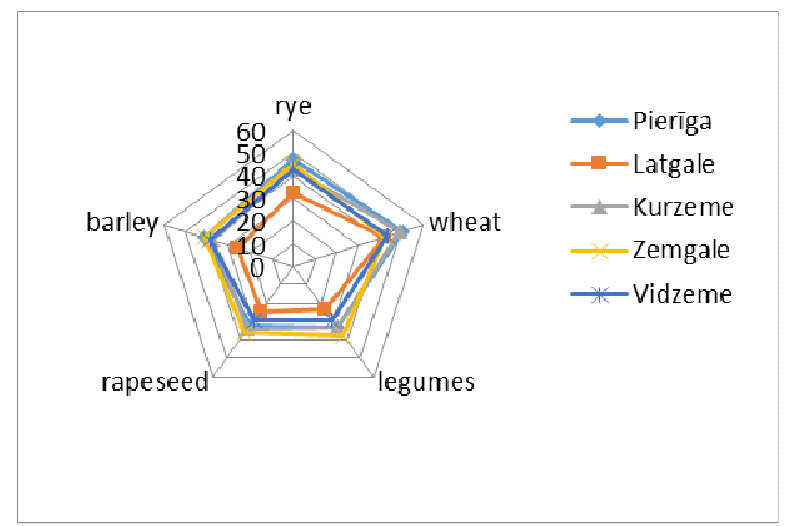

Fig.6. Cereal harvest in Latvian regions 2015

Average cereal harvest in the 2015 in Latgale did not exceed $37 \mathrm{t} / \mathrm{ha}$, while in Zemgale it exceeded 50 t/ha, Kurzeme and Pieriga - 45t / ha. A similar situation is with other indicators.

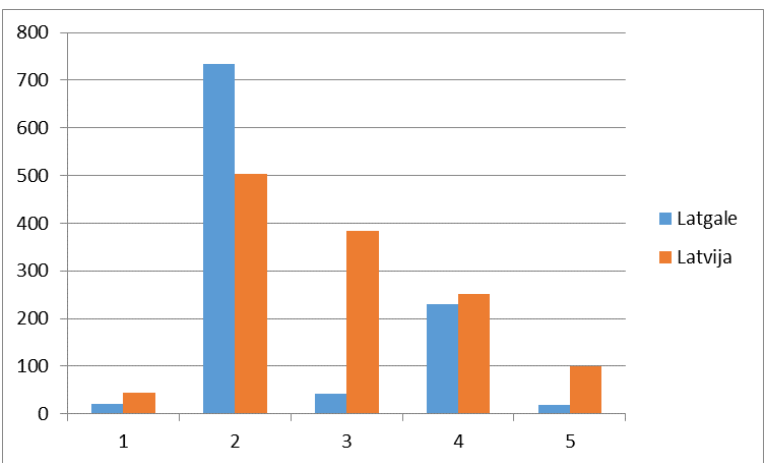

Fig.7. Produced Latvian agricultural production average per capita and Latgale in year 2016. 1-meat, kg ;2-milk, kg ;3-eggs, units; 4potatoes, $\mathrm{kg}$; 5 -vegetables, $\mathrm{kg}$.

The same also applies to the livestock industry. After the number of domestic animals, as well as by the produced quantity Latgale lags behind all other regions in some positions very seriously. For example, Latgale produced a meat almost 6 times less than the Pieriga region and 4 times less than Zemgale region.

In the year 2015 in Latgale was higher than in other regions the number of cows, but also there is less productivity-each cow in Latgale gave only 5 tons of milk per year - about 1-1.7 tons less than in other regions.

Protected natural areas in Latgale despite their great potential is currently not used for human goodwill to meet the needs according to their capabilities.

\section{CONCLUSIONS}

1. The region is dynamic and balanced with the environment complex system-unified on the natural and human communities typical indicators spatially and historically determined territory.

2. According to the genesis of regions they may be natural physical-geographical; ethnic and cultural historical; administrative political.
3. Regional science - interdisciplinary science the object of study of which is the region - its natural, tangible and intangible resources, historical, demographic, ethnic, religious peculiarities of their total interaction, analysis and forecast its development processes.

4. One of the main factors which determinate development of the region are resources, any kind of tangible and intangible values and the sources from which may be obtained the corresponding benefits to the human variety of claims.

5. A resource is a variable in the time, a dynamic concept.

6. Resource exploitation also include ecosystem services.

7. Exactly the rational use of ecosystem services along with the material, energetic and intangible resources of the region are able to activate the regional economic development and human living standards growth.

8. Latvian region of Latgale has a high natural resources and ecosystem services potential, but it is not rationally used.

9. One reason for this situation is a contradiction between the social and geo-spatial region components of existence.

\section{REFERENCES}

[1] Mike Collins, The Pros And Cons Of Globalization, Saving American Manufacturing http://www.manufacturing.net/article/2010/06/pros-and-consglobalization.

[2] R.P.Mishra, Regional planning: Concepts, Techniquers, Policies and Case Studies, Concept Publishing Co, 1992.

[3] Darwent Whittlesey, Major Agricultural Regions of the Earth, Annals of the Association of American Geographers, Feb. 2009.

[4] Peter Holland. Location Theory and the European Union, October 23, 2016 http://www.landisfree.co.uk/sa51-locationtheory-and-the-european-union-by-peter-holland/

[5] Smith, Peter B., Shaun Dugan, and Fons Trompenaars. "National culture and the values of organizational employees a dimensional analysis across 43 nations." Journal of crosscultural psychology 27.2 (1996): 231-264.

[6] Michael E. Porter. "The Five Competitive Forces that Shape Strategy", Harvard Business Review, January 2008, p.86-104.

[7] COMMISSION REGULATION (EU) No $868 / 2014$ of 8 August 2014 amending the annexes to Regulation (EC) No $1059 / 2003$ of the European Parliament and of the Council on the establishment of a common classification of territorial units for statistics (NUTS).

[8] Millennium Ecosystem Assessment 2005 report Ecosystems and human well-being: synthesis. Washington, DC: Island Press. (UNEP 2005).

[9] Crane, David, Paul Fraser, and James D. Phillips. "Western Regionalism: Views on Cascadia." Canada-United States Law Journal, 2004, Vol. 30, p321-347, 22p

[10] Abell, R.,Olson, D.,Dinerstein, E.,Hurley, P. T.,Diggs, J. T.,Eichbaum, W.,Walters, S.,Wettengel, W.,Allnutt, T.,Loucks, C. J.;Hedao, P. "Freshwater ecoregions of North America" Washington, D.C.: Island Press,2000.

[11] Guo, Z.W., X.M. Xio and D.M. Li. 2000. An assessment of ecosystem services: water flow regulation and hydroelectric power production. Ecological Applications 10: 925-936.

[12] Common International Classification of Ecosystem Services (CICES): Consultation on Version 4, August-December 2012. 
[13] 13.Cf. Cosgrove, D.E. Social Formation and Symbolic Landscape, London, 1984

[14] Schama, S.Landscape and memory. New York, Backhaus1995.

[15] Michal Semian \& Pavel Chromý .Regional identity as a driver or a barrier in the process of regional development: A comparison of selected European experience Published online: 25 Sep 2014 Pages 263-270

[16] L. Brūniṇa E.Konstantinova A. Peršēvica. Necessity of Mapping and Assessment of Ecosystems and their Services in Planning and Decision Making Process. LIFE "Ecosystem Services" (LIFE13 ENV/LV/000839) project. 